\title{
A Study of Benzene 1,2,4-Trisphosphate Derivatives as Inositol 1,4,5-Trisphosphate 3-Kinase Inhibitors
}

\author{
Young-Hoon Ahn and Sung-Kee Chung* \\ Department of Chemistry, Division of Holectlar and Life Sciences, Pohang Lniversity of Science \& Technolog, \\ Pohang 790-784, Korea \\ Received December 6, 2001
}

Keywords : Benzene trisphosphate derivatives. Inositol 1.4.5-trisphosphate 3-kinase inhibitors. Knoevenagel condensation.

Inositol 1.4.5-trisphosphate $\left[(1,4.5) \mathrm{P}_{3}\right]$ is a second messenger that mediates the release of $\mathrm{Ca}^{2-}$ from intracellular stores. Although the role of $\mathrm{I}(1.4 .5) \mathrm{P}_{3}$ is well understood much less is known about the roles of its many metabolites. and there are increasing evidences that many of the metabolites possess important functions in their own right. ${ }^{2}$ In particular. $\mathrm{I}(1.3 .4 .5) \mathrm{P}_{4}$. which is derived from $\mathrm{I}(1.4 .5) \mathrm{P}_{3}$ by the action of $\mathrm{I}(1.4 .5) \mathrm{P}_{3} 3$-kinase [IP3K]. is of much current interests. It has been suggested that $\mathrm{I}(1,3.4,5) \mathrm{P}_{4}$ regulates $\mathrm{Ca}^{{ }^{-}}$-influx through the plasma membrane and mobilizes $\mathrm{Ca}^{2+}$ even from the intracellular calcium stores. although less potently than $\mathrm{I}(1.4 .5) \mathrm{P}_{3}{ }^{3}$ Furthermore, putative $\mathrm{I}(1.3 .4 .5) \mathrm{P}_{4}$ binding protein was shown to be a GTPase-activating protein (GAP) activity: suggesting a possible linkage between the PLC-mediated signaling and the ras signaling pathways. ${ }^{+}$It is also an intriguing question whether the IP3K catalyzed process is essential in the in vino synthesis of higher inositol phosphates such as $\mathrm{I}(1.3,4.5,6) \mathrm{P}_{5}$ and $\mathrm{IP} 6$ or simply one of many alternative routes. ${ }^{5}$ Thus. the full characterization of IP3K is critical in order to define the exact role of $\mathrm{I}(1,3,4,5) \mathrm{P}_{4}$ and also to delineate the complex inositol phosphate metabolism

The molecular level characterizations of IP3K have shown remarkable stereo- and regio-selectivities towards the recognition of substrate. $\mathrm{I}(1.4 .5) \mathrm{P}_{3}$, which are higher than that of either $\mathrm{I}(1.4,5) \mathrm{P}_{3}$ receptor or 5-phosphatase. the other key metabolic enzyme. ${ }^{6}$ Recently we studied the binding affinity of IP $3 \mathrm{~K}$ toward all possible 38 regioisomers of inositol phosphates, and proposed an active site model for the enzyme on the bases of the binding data obtained by us and others. ${ }^{7}$ According to this model, apparently all the three phosphate groups of the substrate are needed for the efficient binding. It has also been noted that the enzyme has some vacant space both at the $\mathrm{C}-2$ axial and $\mathrm{C}-3$ axial directions. and that the C-3 space may be occupied by incoming ATP during the phosphory lation.

Several attempts have been ntade to replace the inositol ring of $\mathrm{I}(1,4.5) \mathrm{P}_{3}$ with a hexopyranose. ${ }^{8}$ cyclohexane. and benzene ring. ${ }^{\text {li }}$ It was reported that benzene 1,2.4-trisphosphate $\left(\mathrm{BzP}_{3}\right)$ showed some inhibitory activity of IP3K despite its grossly sumplified planar geometry. In addition, $\mathrm{Bz}_{3}$ displayed somewhat higher affinities for $\mathrm{I}(1.4,5) \mathrm{P}_{3}$ metabolizing enzymes. $\mathrm{I}(1.4,5) \mathrm{P}_{3}$ 3-kinase and 5-phosphatase. than for $\mathrm{I}(1.4,5) \mathrm{P}_{3}$ receptor. ${ }^{10}$ These observations have suggested to us that $\mathrm{BzP}_{3}$ may be utilized as a backbone structure of selective inhibitors of IP $3 \mathrm{~K}$ over the $\mathrm{I}(1,4.5) \mathrm{P}_{3}$ receptor: some suitable modifications of the $\mathrm{BzP}_{3}$ structure based on the binding domain of IP3K may provide more potent inhibitors for IP3K. Thus it was envisaged that the negativelycharged pocket available in the C-2 axial direction may provide a space for an electrophilic moiety to be built onto the $\mathrm{BzP}_{3}$ inlibitor backbone. Based on juxtaposition of $\mathrm{I}(1,4.5) \mathrm{P}_{3}$ with $\mathrm{BzP}_{3}$ a $\mathrm{Bz}_{3}$ derivative in which $\mathrm{H} 5$ was replaced by a suitable electrophilic group was expected to have the desirable geometry as inhibitors of the target enzyme. Designed structures of some possible inhibitors are shown in the Figure 1. Compound 2 is expected to be susceptible to the reversible attack by a nucleoplile on the enzyme at the benzylic carbon. The $\alpha$-chloroketone group as a good electrophile may provide an irreversible inhibitory property to compound $3 .^{11}$ and compound 4 could possibly lead to inactivation of the enzyme through a rearrangement of $\alpha$-cyanoketone to $\alpha$-ketoketenimine ${ }^{12}$ Similarly. $\mathrm{Bz}_{3}$ derivatives tethered with a suitable adenosine moiety might also show inhibitory activity toward IP3K as transition state analogues. For example, compound 5. a structure in which the three phosphates of ATP are replaced with a tether of a similar length, may qualify as a transition state analogue for the phosphorylation. ${ }^{13}$ In the present report we wish to

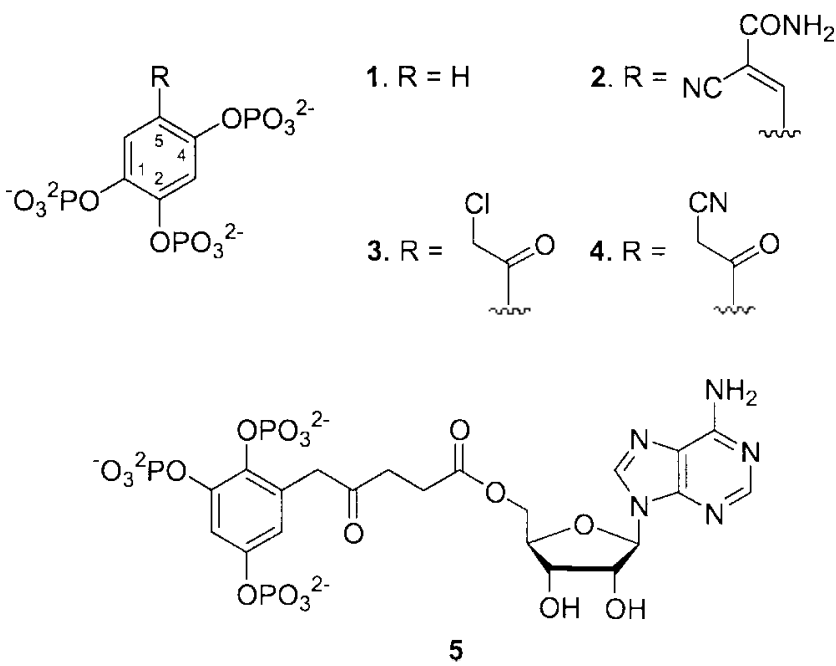

Figure 1. Design of $\mathrm{I}(1,4,5) \mathrm{P}_{3} 3$-kinase inhibitors. 
<smiles>CCCOc1cc(OCCOc2cc(O)c(C=O)cc2O)c(OCOCC)cc1OCC</smiles>

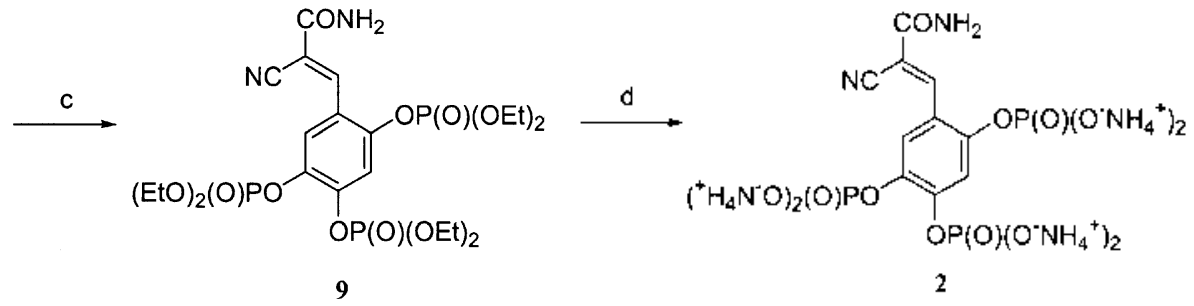

Scheme I. Reagents and conditions: a. (i) $\mathrm{HC}(\mathrm{OEt})_{3}$. $\mathrm{AlCl} \mathrm{l}_{3}$. benzene (ii) $3 \mathrm{~N} \mathrm{HCl}$. 52\%: b. (EtO) 2 POCl. TEA. $\mathrm{CH}_{2} \mathrm{Cl} \mathrm{l}_{2}$. $65 \%$; $\mathrm{c}$. $\mathrm{NCCH}_{2} \mathrm{CONH}_{2}$. piperidine. benmene. $57 \%$. d. (i) $\mathrm{TMSBr} \mathrm{CH}_{2} \mathrm{Cl}_{2}$ (ii) $\mathrm{MeOH}$ (iii) $\mathrm{NH}_{4} \mathrm{OH}$ (pH-9). $80 \%$.

describe the synthesis of the most readily accessible compound 2 , and its inhibitory activity of IP3K.

The synthesis of compound 2 was carried out as outlined in Scheme 1. Commercially available 1,2,4-triacetoxybenzene was hydrolyzed in acidic methanol to obtain 1,2,4benzenetriol 6 . The Friedel-Craft reaction of 6 with triethyl orthoformate in the presence of $\mathrm{AlCl}_{3}$, followed by acidic hydrolysis gave selectively 2,4,5-trihydroxybenzaldehyde 7 , $^{\text {li }}$ The hydroxyl groups of compound 7 were phosphorylated with diethyl chlorophosphate and triethylamine in dichloromethane to give $\mathbf{8}$. The Knoevenagel condensation of $\mathbf{8}$ with 2-cyanoacetamide in the presence of piperidine provided compound 9. The configuration of the double bond was found to be $E$ on the basis of the observation of long distance heteronuclear coupling constant, $J_{\mathrm{IL}}{ }^{13} \mathrm{co}=6.8 \mathrm{~Hz}$. (olefinic proton and carboxyl group) and $J_{14}{ }^{13} \mathrm{CN}^{\mathrm{N}}=13.8 \mathrm{~Hz}$. (olefinic proton and cyano carbon) determined by means of GATED coupling experiments. ${ }^{15}$ No trace of the $Z$ isomer was found in the product mixture. The protecting groups of 9 were removed by treatment with $\mathrm{TMSBr}$. The $\mathrm{pH}$ of the depro-

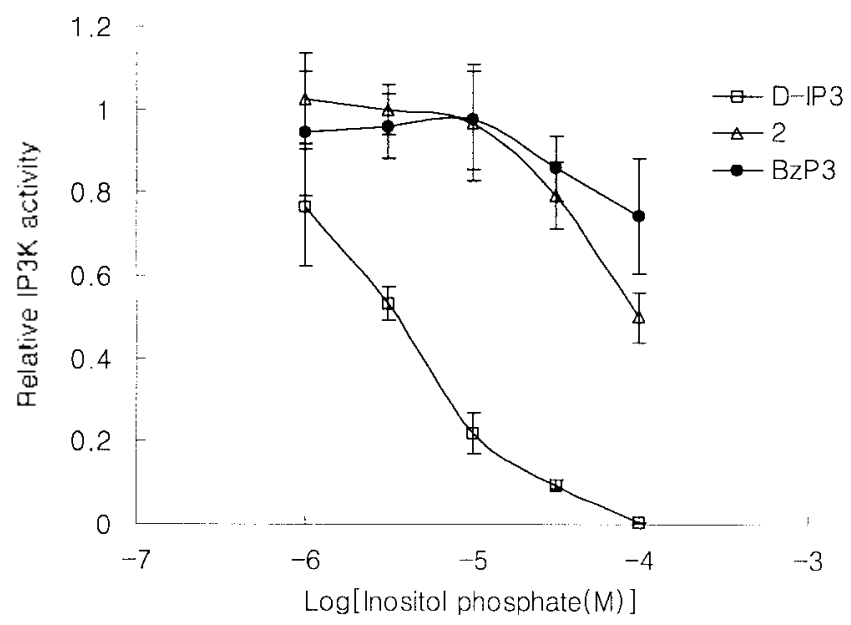

Figure 2. Inlibitory Activities of $(1,4,5) P_{3,2}$ and $13 \% P_{3}$.
Table 1. $\mathrm{IC}_{50}$ Values of $\mathrm{l}(1,4,5) \mathrm{P}_{3,} 2$ and $\mathrm{B} \% \mathrm{P}_{3}$

\begin{tabular}{cccc}
\hline & $\mathrm{D}^{-\mathrm{IP}_{3}}$ & 2 & $\mathrm{BzP}_{3}$ \\
\hline $\mathrm{IC}_{50}(\mu \mathrm{M})$ & 3.5 & 110 & $\cdots 1000$ \\
\hline
\end{tabular}

tected product was adjusted to 9 with $\mathrm{NH}_{4} \mathrm{OH}$, and lyophilized to give essentially pure product 2 , which was fully characterized by spectroscopies.

Compound 2 was tested for its inhibitory activity of IP $3 K$. and it was found to have about 30 times weaker affinity when compared to the substrate, $1(1,4,5) \mathrm{P}_{3}$, but 10 times more potent inhibitory activity than $\mathrm{Bz}, \mathrm{P}$; itself which was also synthesized and tested for direct comparison (Figure 2 and Table 1). However, no time dependent loss of the IP3K activity was observed after incubation of the enzyme with $\mathbf{2}$ over a period of $6 \mathrm{hrs}$ at $0^{\circ} \mathrm{C}$. indicating that 2 is not an irreversible inhibitor of IP3K. In sum, it has been shown that some simple structural modifications on benzene 1,2,4-trisphosphate $\left(\mathrm{Bz}_{\mathrm{s}}\right)$, based on the proposed binding domains of IP3K, could lead to inhibitors with significantly enhanced activity for the target enzyme, and further work along these lines is in progress.

\section{Experimental Section}

General methods. All reactions except hydrolysis were performed in oven-dried glassware under a positive pressure of nitrogen. All solvents were carefully dried and distilled prior to use. Melting points were determined on a thomas Hoover mp apparatus and are uncorrected. IR spectra were recorded on BOMEN F[-IR M100-C15 spectrometer. Analytical TLC was carried out on Merck 60 F254 silica gel plate $(0.25 \mathrm{~mm}$ layer thickness) and visualization was done with UV light, and/or by spaying with a $5 \%$ solution of phosphomolybdic acid followed by charring with a heat gun. Column chromatography was performed on Merck 60 silica gel (230-400 mesh). NMR spectra were recorded on a Bruker AM 300 or DPX spectrometer. Chemical shifts are 
reported in $\delta \mathrm{ppm}$, and tetramethylsilane and phosphoric acid $(80 \%)$ were used as internal and external standard for ${ }^{1} \mathrm{H}-\mathrm{NMR}$ and ${ }^{\hat{1} 1} \mathrm{P}-\mathrm{NMR}$. respectively. Mass spectra were determined on a KRATOS MS 25 RFA. Inhibition of IP3K activity by synthetic compounds was assayed as described previously. ${ }^{16}$

2,4,5-Trihydroxybenzaldehyde (7) ${ }^{1+}$ Compound $6(2.65$ g. $21.07 \mathrm{mmol}$ ) was dissolved in trietlyy orthofomate $(17.0$ $\mathrm{mL} .100 .2 \mathrm{mmol})$ and benzene $(40 \mathrm{~mL}) . \mathrm{AlCl}_{\hat{3}}(3.37 \mathrm{~g} .31 .61$ mmol) was carefully added in portions to the reaction mixture under $\mathrm{N}_{3}$. and the mixture was stirsed for $30 \mathrm{~min}$. After cooling to $0^{\circ} \mathrm{C}, 3 \mathrm{~N} \mathrm{HCl}$ was added dropwise over lhr. Then the solution was extracted with diethyl ether $(\times 2)$ and EtOAc $(\times 2)$. The combined organic layer was washed with brine, dried over $\mathrm{MgSO}_{4}$, and concentrated. After filtration through silica gel/cellite, the organic layer was concentrated to give a solid which was recrystallized from $\mathrm{EtOAc} / \mathrm{Hex}$ to give 7 (1.71 g. $52.3 \%$ ): mp $227-229^{\circ} \mathrm{C}$ (lit. mp $223{ }^{\circ} \mathrm{C}$ ): $\mathrm{R}_{f}$ $0.4($ EtOAc $: \mathrm{Hex}=1: 1) ;{ }^{1} \mathrm{H}-\mathrm{NMR}$ (Acetone-d $) \delta 6.40(\mathrm{~s}$. 1H, Pl-H, H-3). 7.10 (s. 1H, Ph-H, H-6), 9.68 (s, lH. CHO); ${ }^{13} \mathrm{C}-\mathrm{NMR}$ (Acetone- $\mathrm{d}_{6}$ ) $\delta$ 103.06, 113.99. 118.03, 139.15. $155.11,158.52$ (benzene), 194.82 (CHO)

1-Formyl phenyl 2,4,5-tris(diethyl phosphate) (8). To a solution of 7 (300 $\mathrm{mg} .1 .94 \mathrm{mmol})$ in $\mathrm{CH}_{2} \mathrm{Cl}_{2}(10 \mathrm{~mL})$ at $\mathrm{rt}$ were added triethylanine $(0.86 \mathrm{~mL}, 6.19 \mathrm{mmol})$. and then diethyl chlorophosphate $(0.95 \mathrm{~mL} .6 .38 \mathrm{mmol})$ with stirring. After 2 hrs. the reaction mixture was quenched with aq. $\mathrm{NH}_{4} \mathrm{Cl}$, diluted with EtOAc, and washed with $1 \mathrm{~N} \mathrm{HCl}$, aq. $\mathrm{NaHCO}_{3}$ and brine. The organic layer was dried over $\mathrm{MgSO}_{4}$. concentrated. and chromatographed on silica gel (EtOAc $\mathrm{Hex}=2: \mathrm{l})$ to give $8(709 \mathrm{mig} .65 .0 \%): \mathrm{R}_{f} 0.2(\mathrm{EtOAc}: \mathrm{Hex}$ $=2: 1)$ : Oil; ${ }^{1} \mathrm{H}-\mathrm{NMR}\left(\mathrm{CDCl}_{\hat{j}}\right) \delta 1.23-1.42$ (m. $18 \mathrm{H}$. $\left.6 \mathrm{CH}_{3} \underline{\mathrm{CH}}_{3}\right), 4.12-4.36\left(\mathrm{~m}, 12 \mathrm{H}, 6 \mathrm{C} \underline{\mathrm{H}}, \mathrm{CH}_{3}\right), 7.64(\mathrm{~s}, \mathrm{IH} . \mathrm{Ph}-$ H. H-3), $7.86(\mathrm{~s}, \mathrm{lH}, \mathrm{Ph}-\mathrm{H}, \mathrm{H}-6), 10.29$ (s, IH, CHO): ${ }^{13} \mathrm{C}-$ $\operatorname{NMR}\left(\mathrm{CDCl}_{3}\right) \delta \mathrm{l} 6.10-16.19\left(\mathrm{CH}_{2} \mathrm{CH}_{3}\right) .65 .59-65.16\left(\mathrm{CH}_{2} \mathrm{CH}_{3}\right)$. $114.22,120.82,124.52,139.27,147.07,149.87$ (benzene), $186.36(\mathrm{CHO}) ;{ }^{31} \mathrm{P}-\mathrm{NMR}\left(\mathrm{CDCl}_{3}\right) \delta 2.35 .1 .71,1.36$.

1-(2-Carbamoyl-2-cyano-vinyl)-phenyl 2,4,5-tris(diethyl phosphate) (9). To a solution of 8 (497 $\mathrm{mg} .0 .882 \mathrm{mmol})$ in DMF ( $12 \mathrm{~mL})$ and benzene $(20 \mathrm{~mL})$ was added a solution of 2 -cyanoacetanide ( $148 \mathrm{mg}, 1.76 \mathrm{mumol})$ in DMF $(1.0 \mathrm{~mL})$. After addition of 3 drops of piperidine. the solution was refluxed with a Dean-Stark trap for $2 \mathrm{hrs}$. After cooling to rt. the reaction misture was treated with water, diluted with EtOAc. and washed with $1 \mathrm{~N} \mathrm{HCl}$. aq. $\mathrm{NaHCO}_{3}$. and brine. The organic layer was dried, and concentrated to give a solid, which was recrystallized from $\mathrm{EtOAc} / \mathrm{Hex}$ to give 9 (319 mg, 57.4\%): $\mathrm{R}_{f} 0.2(\mathrm{MeOH}: \mathrm{MC}=1: 30): \mathrm{mp} 67-69$ C: IR (neat) $1697(\mathrm{CO}), 2218(\mathrm{CN}):{ }^{\mathrm{H}} \mathrm{H}-\mathrm{NMR}\left(\mathrm{CDCl}_{3}\right) \delta$ $1.36-1.42\left(\mathrm{~m}, 18 \mathrm{H} .6 \mathrm{CH}_{2} \mathrm{CH}_{3}\right), 4.234 .36\left(\mathrm{ml} .12 \mathrm{H} .6 \mathrm{CH}_{3} \mathrm{CH}_{3}\right)$, $6.43,6.55$ (2s, br, 2H, CONH 2 ). 7.63 (s. IH. Ph-H. H-3). 8.30 (s, IH. Ph-H, H-6). 8.56 (s, $1 \mathrm{H}$, benzylic $\mathrm{H}$ ); ${ }^{13} \mathrm{C}-\mathrm{NMR}$ $\left(\mathrm{CDCl}_{j}\right) \delta$ 16.40-16.49 $\left(\mathrm{CH}_{2} \underline{\mathrm{CH}}_{3}\right)$. 65.54-65.92 $\left(\mathrm{CH}_{2} \mathrm{CH}_{3}\right)$. 105.89. 114.49 (styrene), $116.58(\mathrm{CN}) .121 .01,121.30,139.22$. 145.58. 145.84. 147.96 (styrene), 161.82 (CO); ${ }^{31} \mathrm{P}-\mathrm{NMR}$ $\left(\mathrm{CDCl}_{3}\right)$ 33.76. 4.38, 4.67; $\mathrm{MS}(\mathrm{FAB}) m: 2629\left(\mathrm{M}^{-}+\mathrm{H}\right)$.
Ammonium salt of 1-(2-carbamoyl-2-cyano-vinyl)-phenyl 2,4,5-trisphosphoric acid (1). To a solution of $9(307 \mathrm{mg}$. $0.488 \mathrm{mmol})$ in $\mathrm{CH}_{2} \mathrm{Cl}_{2}(6 \mathrm{~mL})$ at $20^{\circ} \mathrm{C}$ was added excess TMS-Br $(2.71 \mathrm{~mL}, 20.45 \mathrm{mmol})$ and the solution was stirred for 2 days. The reaction mixture was quenched with $\mathrm{MeOH}(6 \mathrm{~mL})$. and evaporated to dryness. The reaction mixture was redissolved in $\mathrm{H}_{2} \mathrm{O}(5 \mathrm{~mL})$ at $0^{\circ} \mathrm{C} . \mathrm{pH}$ was adjusted to 9 with $\mathrm{NH}_{4} \mathrm{OH}$, and lyophilized to give ammonium salt 2 (262 $\mathrm{mg}$ ) in ca. $80 \%$ yield: IR ( $\mathrm{KBr}$ pellet) $2360.2340 \mathrm{~cm}^{-1}$ (CN); ${ }^{1} \mathrm{H}-\mathrm{NMR}\left(\mathrm{D}_{2} \mathrm{O}\right) \delta 7.4 \mathrm{l}$ (s. IH. Plh-H. H-3). 8.23 (s, lH, Ph-H. H-6), 8.51 (s, IH, benzylic H): ${ }^{13} \mathrm{C}$ NMR (D 2 ) $\delta 101.52 .111 .83$ (styrene), $117.49(\mathrm{CN}) .118 .96$. 120.05. 139.70. 147.71. 150.44. 151.23 (styrene) 166.56 (CO): ${ }^{3]}$ P-NMR $\left(\mathrm{D}_{2} \mathrm{O}\right)$ d $1.68 .1 .60,1.41$.

Acknowledgment. This work was supported by the Korea Science \& Engineering Foundation/Center for Biofunctional Molecules and the Korea Research Foundation/BSRI Fund. We thank Dr. Gildon Choi in the laboratory of Professor Kwan Yong Choi for the assistance in the inlibition bioassays.

\section{References}

1. Berridge, M. J. Nature 1993,361.315

2. (a) Fukuda. M.: Mikoshiba. K. Bioeswa 1997. 19.593: (b) Shamsuddit1. A. M. AntiCancer Res. 1999. 19. 3733: (c) Chi. T. H.: Crabtree. G. R. Science 2000. 287. 1937: (d) Odom. A. R.: Stahlberg, A.: Wente, S. R: York. J. D. Science 2000. 287. 2026.

3. (a) Irvine. R. F. FEBS Lett. 1990. 263. 5: (b) Irvine, R. F. Biaassaus 1991. 13.419.

4. Cullen. P. J.: Hsuan. I. T.: Truong. O.: Letcher. A. J.: Jackson. I. R.: Dawson. A. P.: Irvine. R. F. Natthe 1995. 376.527

5. Menniti. F. S.: Oliver. K. G.: Putney. T. W. Tr:: Shears. S. B Trends in Biochem. Sci. 1993. 18, 53 .

6. (a) Narhorski, S. R; Potter. B. V. L. Trends in Phamacol. Sci 1989. 10, 139; (b) Potter. B. V. L.; Lampe. D. Angew. Chem. Int. Ed. Engl. 1995. 34. 1933

7. Chung. S. K.: Choi. K. Y.: Choi. G.: Chang. Y. T. Bioong. Med. Chent Lett. 1997. 7. 2709.

8. (a) Shuto, S.: Yahiro, Y; Ichikawa, S.: Matsuda. A. J. Org. Chem 2000. 65, 5547: (b) Abe, H; Shuto, S.; Matsuda, A. J. Org. Chem 2000. 65,4315 : (c) Chung, S. K.: Moon, S. H. J. Chem. Soc. Chent Conmum. 1992. 77

9. (a) Kozikowski. A. P.: Ognyanov. V. I.: Chen. C.: Kurian. P.: Crews. F. T. Tetrohedron Lett. 1993. 34. 219: (b) Polokoff. M. A.: Bencen. G. H.; Vacea. J. P.; deSolms, S. J; Young, S. D.; Huff. J. R. J. Biol. Chem 1988. 263, 11922.

10. Poitras, M; Bernier. S.: Boulay, G.; Foumier. A.: Guillemette. G. Eur. J. Pham. 1993. 2H. 203.

11. Otto. H. H.: Schirmeister. T. Chent. Rev 1997.97. 133.

12. (a) Mobashery. S.: Ghosh. S. S.: Tamura. S. Y.: Kaiser. E. T. Proc. Natl Acad. Sci. USA 1990. 87, 578: (b) Ghosh, S. S.; Wu. Y. Q: Mobashery, S. J. Biol. Chem. 1991. 266.8759.

13. (a) Schramm. V. L. Amu. Rev Biochem. 1998. 67,693: (b) Kruse. C. H.: Holden. K. G.: Pritchard. M. L.: Field. T. A.: Rieman. D. . .: Greig. R. G.: Poste. G. J. Med Chent 1988. 31. 1762 \& 1768.

14. Gross. H.: Rieche. A.: Matthey. G. Chentical Abstracts 1963. 58. $10110 \mathrm{~d}$.

15. Kingsbury. C. A.: Draney. D.: Sopehik, A.: Rissler, W.: Durham, D. J. Org. Chem. 1976, 41.3863.

16. Choi. G.: Chang. Y. T.: Chung. S. K.: Choi. K. Y. Kor J. Med. Chent 1997. 7. 106. 